Adem Kilicman - Wah June Leong

Zainidin Eshkuvatov Editors

International

Conference on

Mathematical

Sciences and

Statistics 2013

Selected Papers

Springer 
International Conference on Mathematical Sciences and Statistics 2013 
Adem Kilicman • Wah June Leong Zainidin Eshkuvatov

Editors

\section{International Conference on Mathematical Sciences and Statistics 2013}

Selected Papers

算 Springer 


\section{Editors}

Adem Kilicman

University Putra Malaysia

Serdang, Selangor

Malaysia

Wah June Leong

University Putra Malaysia

Serdang, Selangor

Malaysia

\author{
Zainidin Eshkuvatov \\ University Putra Malaysia \\ Serdang, Selangor \\ Malaysia
}

ISBN 978-981-4585-32-3

ISBN 978-981-4585-33-0 (eBook)

DOI 10.1007/978-981-4585-33-0

Springer Singapore Heidelberg New York Dordrecht London

Library of Congress Control Number: 2014931491

(C) Springer Science+Business Media Singapore 2014

This work is subject to copyright. All rights are reserved by the Publisher, whether the whole or part of the material is concerned, specifically the rights of translation, reprinting, reuse of illustrations, recitation, broadcasting, reproduction on microfilms or in any other physical way, and transmission or information storage and retrieval, electronic adaptation, computer software, or by similar or dissimilar methodology now known or hereafter developed. Exempted from this legal reservation are brief excerpts in connection with reviews or scholarly analysis or material supplied specifically for the purpose of being entered and executed on a computer system, for exclusive use by the purchaser of the work. Duplication of this publication or parts thereof is permitted only under the provisions of the Copyright Law of the Publisher's location, in its current version, and permission for use must always be obtained from Springer. Permissions for use may be obtained through RightsLink at the Copyright Clearance Center. Violations are liable to prosecution under the respective Copyright Law.

The use of general descriptive names, registered names, trademarks, service marks, etc. in this publication does not imply, even in the absence of a specific statement, that such names are exempt from the relevant protective laws and regulations and therefore free for general use.

While the advice and information in this book are believed to be true and accurate at the date of publication, neither the authors nor the editors nor the publisher can accept any legal responsibility for any errors or omissions that may be made. The publisher makes no warranty, express or implied, with respect to the material contained herein.

Printed on acid-free paper

Springer is part of Springer Science+Business Media (www.springer.com) 


\section{Preface}

The 2013 International Conference on Mathematical Sciences and Statistics (ICMSS2013) was held in Kuala Lumpur, Malaysia on 5-7th February, 2013. This conference is aimed to bring together scholars, leading researchers, and experts from diverse backgrounds and applications areas in mathematical sciences and statistics. Special emphasis is placed on promoting the interaction between the theoretical, experimental, and applied communities, so that a high-level exchange in new and emerging areas within mathematics, statistics, and its related applications in sciences is achieved. We are pleased that many friends and colleagues, postgraduate students as well as many practitioners and other scientists, were attracted by the goals of this recent event and offered to contribute to its success.

This volume contains 29 articles chosen from 172 contributions presented at ICMSS 2013. These were selected with a careful eye to their scientific quality and relevance to the specific topics of the conference, or more general methods and tools for statistical analysis. The articles explore a variety of topics, including mathematical analyses, probability, statistics, algebra, geometry, mathematical physics, wave propagation, stochastic processes, ordinary and partial differential equations, boundary value problems, linear operators, cybernetics, and number and functional theory.

We are grateful to the Department of Mathematics, Faculty of Science, Universiti Putra Malaysia (UPM), and all those who have supported the conference, and in particular the members of the organizing committee, for their dedication and activity. We would like to thank the authors for their valuable contributions, the referees for their priceless efforts of reviewing the manuscripts, and Professor Dr. Fudziah Ismail, Head of Department of Mathematics, UPM for encouraging us and making this volume realized.

November, 2013

Adem Kilicman Wah June Leong Zainidin Eshkuvatov 


\section{Contents}

On Seven-Dimensional Filiform Leibniz Algebras ............... 1

Abdulafeez O. Abdulkareem, I. S. Rakhimov and S. K. Said Husain

On Exponential Stability of Stochastic Control Systems ............. 13

Fakhreddin Abedi and Wah June Leong

On the Solution of Singular Ordinary Differential Equations Using a Composite Chebyshev Finite Difference Method ........... 21

A. Kazemi Nasab, Z. Pashazadeh Atabakan, A. Kilicman and Zainidin K. Eshkuvatov

On 0-Controllability and Pursuit Problems for Linear Discrete Systems Under Total Constraints on Controls ................. 31

Atamurat Kuchkarov, Gafurjan Ibragimov and Akmal Sotvoldiev

Construction of Strategies of Pursuers in a Differential Game of Many Players with State and Integral Constraints

Gafurjan Ibragimov, Asqar Rahmanov and Idham Arif Alias

A Triangular Stochastic Facility Layout Problem in a Cellular Manufacturing System ............................. 45

Shahram Ariafar, Zahra Firoozi and Napsiah Ismail

Constructing a Three-Stage Asymptotic Coverage Probability

for the Mean Using Edgeworth Second-Order Approximation ........ 53

Ali S. Yousef

Mathematical and Numerical Modelling of the Thermoplastic

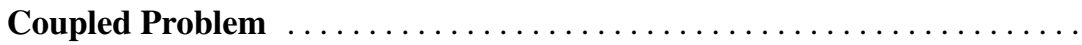

Abduvali A. Khaldjigitov, Nik Mohd Asri Nik Long, Aziz Qalandarov

and Zainidin K. Eshkuvatov 
New Modification of Laplace-Adomian Decomposition Method for the Fifth-Order KdV Equation

H. O. Bakodah and B. S. Kashkari

Extended Simpson Rule for Solving First-Order Fuzzy Differential Equations Using Generalized Differentiability

Reza Afsharinafar, Fudziah Ismail, Mohamed Suleiman and Ali Ahmadian Hosseini

Modified Decomposition Method for Solving Nonlinear

Volterra-Fredholm Integral Equations

F. S. Zulkarnain, Z. K. Eshkuvatov, Z. Muminov and N. M. A. Nik Long

Solution of Second Order Ordinary Differential Equations by Direct Diagonally Implicit Block Methods

Nooraini Zainuddin, Zarina Bibi Ibrahim, Mohamed Suleiman,

Khairil Iskandar Othman and Yong Faezah Rahim

Group Algebra Codes Define Over Extra-Special $p$-Group

Denis C. K. Wong

New Subclasses of Meromorphic Functions Related

to Cho-Kwon-Srivastava Operator

Firas Ghanim and Maslina Darus

The Description of Orbits Under an Action of $G L_{9}$ ON $S L b_{9}$

I. S. Rakhimov, S. K. Said Husain and F. Deraman

Effects of Magnetohydrodynamic on the Stagnation Point Flow past a Stretching Sheet in the Presence of Thermal Radiation with Newtonian Heating

Muhammad Khairul Anuar Mohamed, Muhammad Imran Anwar,

Sharidan Shafie, Mohd Zuki Salleh and Anuar Ishak

Description of Three Dimensional Solvable Evaluation Algebras . . . . . . 165

Farrukh Mukhamedov, Bakhrom Omirov and Izzat Qaralleh

On Quasi Quantum Quadratic Operators of $M_{2}(C) \ldots \ldots \ldots \ldots \ldots \ldots$

Farrukh Mukhamedov and Abduaziz Abduganiev

On the Structure of the Essential Spectrum of Four-Particle

Schrödinger Operators on a Lattice

Z. Muminov, F. Ismail and Z. Eshkuvatov

Symmetrizers for Runge-Kutta Methods

N. Razali and R. P. K. Chan 
A Method of Estimating the $p$-adic Sizes of Common Zeros of Partial Derivative Polynomials Associated with a Complete Cubic Form

S. S. Aminudin, S. H. Sapar and K. A. Mohd Atan

Feynman Graph Representation to Stochastic Differential Equations

Driven by Lévy Noise

Boubaker Smii

Some Properties of the Concurrent Grammars

Gairatzhan Mavlankulov, Mohamed Othman, Mohd Hasan Selamat and Sherzod Turaev

Statistical Analysis on LBlock Block Cipher

Nik Azura Nik Abdullah, Kamaruzzaman Seman and Norita Md Norwawi

A New Threshold-Authenticated Encryption Scheme

Mohd Saiful Adli Mohamad, Eddie Shahril Ismail and Haslinda Ibrahim

On Differential Invariants of Some Classical Groups $\ldots \ldots \ldots \ldots \ldots \ldots \ldots$

Ural D. Bekbaev and Isamiddin S. Rakhimov

Structure of Relative Relation Modules of Finite Groups .

Mohammad Yamin and P. K. Sharma

Block Methods with Off-Steps Points for Solving First Order Ordinary Differential Equations

Lee Ken Yap and Fudziah Ismail

Implicit Finite Difference Solutions of One-Dimensional Burgers'

Equation Using Newton-HSSOR Method

J. Sulaiman, M.K. Hasan, M. Othman and S.A.A. Karim 